OPAL Online Paper Series | 12/2013

\title{
National Parliaments after Lisbon: Administrations on the Rise?
}

Anna-Lena Högenauer \& Christine Neuhold

Sponsored by: 
This online paper series is published by the

Observatory of Parliaments after the Lisbon Treaty (OPAL).

OPAL is a scientific consortium comprising researchers from four partner institutions:

Maastricht University

SciencesPo.

囦圈 UNIVERSITY OF

University of Cologne

OPAL Online Papers are published at www.opal-europe.org.

Series Editors: Thomas Christiansen \& Ariella Huff

ISBN: 978-94-9|704-02-4 


\title{
National Parliaments after Lisbon: Administrations on the Rise?
}

\author{
Anna-Lena Högenauer \& Christine Neuhold
}

\begin{abstract}
In the wake of the Lisbon Treaty, much of the academic debate on national parliaments (NPs) in EU politics has focused on the new powers of NPs and the potential for the politicization and parliamentarization of EU politics. In the process, the role of administrators in the parliamentary control of EU affairs has been neglected. By contrast, this paper argues that the strengthening of NPs has in fact gone hand in hand with a strengthening of the role of parliamentary administrators owing to the increased demand for information and expertise that are prevalent due to the Lisbon provisions.
\end{abstract}

After reviewing the most important provisions of the Treaty of Lisbon on national parliaments, the paper discusses the roles of parliamentary administrations in the scrutiny of EU affairs and the exercise of political oversight over their activities. The concluding section discusses the extent to which the Treaty of Lisbon can be said to have triggered a rise of parliamentary administrations. 


\title{
National Parliaments after Lisbon: Administrations on the Rise?
}

\author{
Anna-Lena Högenauer \& Christine Neuhold
}

\section{Introduction}

The role of administrators in the functioning of national parliaments is routinely overlooked in the European literature. This is to some extent natural. Parliaments are seen as political arenas and highly political institutions, and commentators thus focus on the "political" actors in the parliaments and their "political" activities - control of the executive, debates and party politics. This paper argues that such a focus obscures the roles of administrators in the functioning of parliaments. This is problematic to the extent that these roles go beyond the merely technical or secretarial.

The focus of this paper lies on the role of parliamentary administrations ${ }^{1}$ in the scrutiny of EU politics and, in particular, on parliamentary administrations after the Treaty of Lisbon as a development that brings the question of administrative support to the fore. The issue of the involvement of national parliaments in EU policy-making has been on the agenda for over a decade, in particular since the Laeken Declaration (European Council, 2001). It was raised in response to concerns over the democratic deficit of the European Union (EU) in the hope that a greater involvement of directly elected national politicians would give EU decision-making greater legitimacy and contribute to the communication of European issues to the citizens. Thus, the new provisions on national parliaments of the Constitutional Treaty remained virtually unchanged in the Lisbon Treaty (Raunio, 2007).

While it remains subject to debate how much influence national parliaments have gained under the new provisions, the provisions do provide national parliaments with a set of opportunities. Apart from symbolic changes such as the mentioning of national parliaments as a contributor to the "good functioning of the European Union" in Article 12 TEU, the Treaty of Lisbon strengthens the information rights of national parliaments and provides new channels of action. ${ }^{2}$

\footnotetext{
${ }^{1}$ The focus of this paper lies on the parliamentary staff itself rather than the experts employed by party groups or individual MPs.

${ }^{2}$ For further information, see the protocols annexed to the Lisbon Treaty: Protocol on the role of national parliaments in the EU; Protocol on the application of the principles of subsidiarity and proportionality.
} 
Firstly, the protocol on the role of national parliaments guarantees parliaments wide-ranging information rights with regard to Commission consultation documents, instruments of legislative planning and draft legislative acts as well as the agendas and minutes of Council meetings (Articles 1 and 2).

Secondly, the control and participation rights of national parliaments are improved. Thus, each national parliament can veto the move from unanimity to qualified majority voting or from a special legislative procedure to the ordinary legislative procedure under the passerelle clauses. National parliaments are to be involved in the revision procedures of the Treaties and to take part in the monitoring of Europol and Eurojust. Most importantly, under the new "Early Warning system" (EWS), any chamber of a national parliament may review the compliance of a legislative proposal with the principle of subsidiarity. If the chamber finds the proposal to be in breach of the principle of subsidiarity, it can - within 8 weeks from the date of transmission of the legislative act - send a reasoned opinion to the Presidents of the EP, the Council and the Commission explaining (or any other institution putting forward the proposal, if appropriate; for example the European Central Bank) why it considers the proposal to be in breach of subsidiarity. If a certain number of chambers object to the proposal on grounds of subsidiarity, the national parliaments can issue a "yellow" or "orange card" (depending on the number of reasoned opinions). The European institution that issued the proposal can then decide to amend, revise or withdraw its proposal and has to justify its decision, but the objections of the national parliaments alone cannot force an institution to withdraw or amend a proposal. A proposal only fails if one of the three European institutions, the Commission, the Council or the European Parliament, supports the view of the national parliaments (cf. Christiansen, Hoegenauer, Neuhold 2011: 2-4, Raunio 2007, Kiiver 2012).

The introduction of the very novel Early Warning System triggered a vibrant debate about the level of influence that parliaments can have in practice, the coordination problems between national parliaments and the new procedures put in place by parliament in response to the Lisbon provisions (e.g. Kiiver 2012, Cooper 2012, Raunio 2010). However, a question that was largely overlooked by academics is the question of how this affects the role of parliamentary administrations.

One could expect the role of parliamentary administrations to increase for two reasons. Firstly, the Early Warning System and new information rights not only present opportunities but also put pressure on the organization of parliamentary business. The Lisbon changes require parliaments to filter and digest an increased amount of information, identify priorities and problems and react within a very narrow time span of only eight weeks. As the EWS is limited to objections on grounds of subsidiarity, the reasoned opinions need to be carefully worded and be based on 
(legal) justifications, and as a certain number of reasoned opinions are necessary to trigger a card, coordination with other parliaments is not only desirable but a necessity. There may thus be a need to involve the parliamentary administration in the process and even to reform existing structures. The problems that these pressures can create are best illustrated by the Belgian case. Because of the federal structure of the Belgian state, Belgium decided to allow its regional parliaments to issue reasoned opinions in policy areas that fall under their competence. However, to date, none of the regional parliaments has issued a reasoned opinion, which is seen as the result of a lack of capacity on the part of those parliaments. In fact, the parliament of Brussels had to temporarily opt out of the information distribution system, as it could not manage the sheer volume of EU-related information on a purely administrative level, let alone scrutinize the documents (Belgian Senate, EAC official, 16/o4/2012; Belgian House of Representatives, EAC official, 25/05/2012). Secondly, the high complexity of European legislation and perceived low salience of most EU issues are two features that make a delegation of tasks to administrators more likely, according to the literature on administrations (Manley, 1968).

The paper thus raises the question as to the extent to which parliamentary administrations actually do play an active part in the scrutiny of EU politics; the roles that are fulfilled by administrators in the process and the ways in which politicians exercise oversight over the parliamentary staff. In addition, the pressures on national parliaments raise the question whether the attempts to politicize European policy-making in the Lisbon Treaty were in fact accompanied by a trend of bureaucratization.

In order to address these questions, we will first examine the roles that parliamentary administrators currently play in the scrutiny of EU affairs, while trying to distinguish which parts of these roles developed in response to the Lisbon Treaty. This will be done on the basis of qualitative data. Between September 2010 and June 2012 a first batch of semi-structured interviews with committee clerks and MPs from eight member states was conducted within the framework of a larger project on national parliaments after Lisbon (OPAL): the UK (House of Commons), France, Belgium, Germany (Bundesrat), the Netherlands, Sweden, Austria and Romania as well as Parliamentary Representatives in Brussels also from Slovenia, Finland and Ireland. In addition, the authors have so far received written replies to a questionnaire from the French Senate, the Austrian, Belgian and Swedish parliaments and the German Bundesrat. ${ }^{3}$ This case selection could not be based on criteria related to the role or performance of parliamentary administrations, as the academic debate is rather silent on this and parliaments provide limited information, e.g. on parliamentary websites. However, there is variation on two other criteria that potentially affect the role of administrations: the focus on document-based scrutiny or mandating and the size of

\footnotetext{
${ }^{3}$ For a complete list of interviews used for this paper please refer to the bibliography.
} 
the parliament. The size of the parliament is relevant in that smaller parliaments are likely to have smaller administrations and thus less administrative capacity. However, the amount of EU documents received per year is the same as for larger parliaments. Thus, the size of the parliament and its administration are likely to have an impact on the role that the administration can play. The difference between mandating and document-based scrutiny lies in the question of salience and political importance attributed to a certain issue. As mandating is a form of negotiation between governments and parliaments, party politics and opposition dynamics may play a bigger role when politically important issues are at stake than in the scrutiny of EU documents in general. This makes it less likely that the administration is allowed to play an important role.

In order to answer the questions about administrative involvement and roles, the first section will first review the existing literature on bureaucrats and on the administration of the European Parliament. A new typology of roles of parliamentary administrators is developed and differences in the extent of administrative involvement discussed. The second section then turns to the question of political oversight, i.e. the extent to which MPs and Senators retain control over the final outcomes of parliamentary scrutiny. The concluding section analyses the extent of bureaucratization of parliamentary scrutiny of EU affairs and presents questions for further research. While the focus of the paper thus lies on one policy arena, it is likely that the general conclusions on the role of parliamentary administrations are valid in domestic politics as well.

\section{Parliamentary Administrations in EU Affairs: Mere Paper- Pushers?}

\section{I.I How to Define What Bureaucrats Do?}

The complexity of the modern state and the issues at stake in policy-making require politicians to delegate some tasks and certain decision due to a lack of time and expertise. Usually this delegation empowers bureaucratic actors who specialize in certain fields. This can be seen in the case of executives, where policies are often drawn up and managed by the bureaucratic layers, which led Guenther Verheugen, for example, to complain about the power struggle between Commissioners and civil servants when he was Vice President of the Commission (EU Observer, 5 October 2006).

However, a similar dilemma befalls politicians in legislatures, who also need to delegate certain decisions due to time constraints (Arnold, 1987: 279). Any type of legislative or control activity on the part of legislatures usually requires a certain amount of information gathering and processing, which one can expect to be at least partially delegated to the parliamentary administration and, 
especially, committee staff. Thus, in the context of the European Parliament (EP), Neunreither points out that even rapporteurs are not likely to be experts on the issue that they have to follow, both because of their own background and the way in which committee-membership and tasks get distributed in parliaments. He argues that - in national parliaments - the majority parties can rely on information from the government (Neunreither, 2006: 45). However, the new Early Warning System and information rights of national parliaments have led to increased pressure on the organization of parliamentary business, which means that European Affairs is a policy area that is particularly likely to see delegation to bureaucrats. In addition, some parliaments see the EWS as an opportunity to gain influence independently from their government, which can lead even governing parties to be in favour of independent information gathering (Dutch Lower House, VVD MP, 28/03/2012). In the end, what kind of roles can we expect administrators to fulfil?

The literature on European national parliaments provides little insights in that regard. Parliamentary administrations in Western Europe have thus-far been the subject of mainly descriptive analysis (Campbell and Laporte, 1981; Ryle, 1981, Harfst and Schnapp 2003, Perez 2007). Baron highlights the emphasis on political neutrality in the French system and mentions both an advisory role and an increasing involvement in the drafting of laws, amendments and reports (Baron, 2013). Independence and autonomy from governments are essential characteristics of not only of the French but also of the British parliamentary administrative system (Campbell and Laporte, 1981; Ryle, 1981; Perez, 2007). Parliaments need their own source of information and expertise in order to remain independent from the government. In Germany, the civil service of parliament is, however, covered by the same legal framework as the federal bureaucracy, which is to provide for mobility between the legislative and executive bureaucracy (Schramm 1965, in: Blischke 1981, in: Pegan 2011). This is similar to the EU where the Staff Regulations of Officials of the European Communities apply to the Commission, the Council and the EP alike (European Communities 2004).

For the administration of the US Congress, Patterson summarized the tasks as informationgathering, the planning of hearings and drafting (Patterson, 1970: 26) Alternative resources in the literature are the typologies that have been developed with regard to bureaucrats in executives and the nascent literature on the EP. Page and Jenkins, for example, develop a typology of policy roles in the context of mid-level bureaucrats in the UK. They distinguish between a production role, when bureaucrats draw up policy-related documents, a maintenance role, when bureaucrats manage policies and a service role when they advise a particular body or person (Page \& Jenkins, 2005: 60-75). While the production and service role are likely to be relevant in a parliamentary context where MPs may also rely on advice and drafts from the parliamentary administration, the maintenance role is a typical executive role. We do indeed know from the literature on the US 
Congress that parliamentary administrations provide substantial advice in complex policy areas, to the point where it can be a problem for minority parties if the advice is politically biased (Manley, 1968). However, the typology also contains gaps with regard to the tasks of parliamentary administrations, as it does not capture information management, which is likely to be important in parliaments, especially with regard to European Affairs.

In that respect, the literature on the European Parliament may be more instructive, as it should capture some features that are particularly important for parliaments. However, this body of literature is still fairly narrow. According to Provan (2001; cited in Neunreither, 2006: 55), assistance to EP Committees and MEPs can be broken down into technical-administrative assistance, which consists of organisational support, technical-substantive assistance, which involves procedural advice and assistance with drafting, research assistance and, lastly, political assistance, which is defined as political co-ordination within or across political groups and policy definition. Provan recommended that political assistance be left to the staff of political groups and the assistants of MEPs (Provan 2011). This breakdown is detailed, but the description of all tasks that might fall to the parliamentary administration as "technical" might downplay the role of administrators and hide the extent to which decisions are delegated. Winzen questions more openly the extent to which the work of the EP staff is merely technical or also of relevance to public policy, and in the process defines two roles: managing the process and informing the process (Winzen, 2011). This distinction is, of course, very broad and makes it difficult to capture change. Egeberg, Gornitzka, Trondal and Johannessen (2012) also examine the activities of EP staff by way of an online survey $(\mathrm{N}=118)$ When zooming in on what officials actually do, i.e. what tasks they (say they) perform it becomes apparent that providing background information for MEPs ranks at the top, followed by drafting documents (Egeberg et.al 2012, p. 17).

Dobbels and Neuhold (2012) have attempted to apply the roles developed by Page and Jenkins to the EP:

1. For the EP the production role would imply the drawing up of meeting documents, such as the agenda, voting lists on amendments and compiling the draft reports that are under discussion. This would be done on the basis of the input given by other members and on instruction of the rapporteur in question.

2. A service role in the EP would be to supplement the production role by supplying personal knowledge to MEPs on the substance of the draft reports and guidance as regards to legal and procedural issues (Egeberg et.al 2012, p. 17)

3. Due to the fact that EP officials operate at the heart of the EU policy-process the authors posit that EP officials could perform a role that goes beyond the service role defined by Page and Jenkins; a role which could be classified as a steering role. This would imply that EP civil 
servants are substantially influencing the item at stake beyond the instructions of MEPs (or because of the lack thereof).

Based on the insights from the existing literature and on interviews with Dutch and Belgian officials, the following typology has been developed (Table 1). In a first deductive process, the distinction between 'technical' tasks and informational tasks (e.g. Winzen, 2011; Neunreither, 2006) was kept. In addition, the specific tasks mentioned in the literature were tied to this distinction. However, after the first interviews, the decision was taken to create a further category to capture the nuances in 'non-technical' tasks as well as the category of 'coordinator', which is necessary to cover the specific tasks of administrators in inter-parliamentary cooperation. For example, Page and Jenkins' production role (2005: 60-75) captures the fact that administrators produce drafts. But the first interviews showed that some administrations produce drafts prior to committee meetings and some only after committee meetings based on the discussions of the MPs. Similarly, some administrations try to provide a list of all possible arguments whereas some make specific recommendations. Thus, not all administrators that analyze EU affairs for their committee also provide concrete advice.

Table I: Roles and tasks of parliamentary administrators in EU Affairs

\begin{tabular}{|c|c|c|c|c|}
\hline Roles & $\begin{array}{l}\text { Administrative } \\
\text { Assistant }\end{array}$ & Analyst & Advisor & Coordinator \\
\hline Tasks & $\begin{array}{l}\text { - Gathers and } \\
\text { forwards } \\
\text { information } \\
\text { - Summarizes } \\
\text { information } \\
\text { - Organises } \\
\text { committee } \\
\text { meetings }\end{array}$ & $\begin{array}{l}\text { - Provides } \\
\text { choice of } \\
\text { balanced } \\
\text { arguments } \\
\text { - Provides } \\
\text { drafts after } \\
\text { debates } \\
\text { - Provides } \\
\text { procedural } \\
\text { and legal } \\
\text { advice }\end{array}$ & $\begin{array}{l}\text { - Pre- } \\
\text { selection of } \\
\text { documents } \\
\text { - Provision of } \\
\text { concrete } \\
\text { solutions } \\
\text { - Drafts also } \\
\text { prior to } \\
\text { debates }\end{array}$ & $\begin{array}{l}\text { - Coordination with } \\
\text { executive } \\
\text { - other chambers/ } \\
\text { Parliaments } \\
\text { - EU institutions }\end{array}$ \\
\hline $\begin{array}{l}\text { Extent of } \\
\text { involvement } \\
\text { in scrutiny }\end{array}$ & Low & Low- medium & Medium-high & Low-medium \\
\hline
\end{tabular}

The table now distinguishes four different types of staff roles. If administrators adopt the first type of role, they have a very low involvement in the actual process of scrutiny and act as administrative assistants. They merely gather and forward information without discriminating between issues, summarize the information provided and focus on the organization of parliamentary business. A second type of administrator is more active in the process of scrutiny 
and plays the role of analyst, but without exercising too much influence on the content of the discussions. Thus, that type of administrator provides a choice of arguments before a debate, that allows MPs to choose between different alternatives or pro and contra arguments, for example on whether a proposal is in breach of subsidiarity, but the administrator does not recommend a specific course of action. This type of administrative action also comprises procedural advice and drafts parliamentary documents on the basis of debates. Administrators that take on the role of advisors would engage in the pre-selection of "relevant" documents/issues and thus play an agenda-setting role. They would not only present MPs with arguments, but recommend a certain solutions and they would thus also be able to draft documents prior to debates. Finally, administrators can fulfil a coordinating function vis-à-vis other national parliaments, European institutions or their own government. The category is set apart in the table, as it does not say much about influence in itself. Coordination can mean information gathering, but it could also imply a representational function vis-à-vis other actors in Brussels or at home and can in the best of cases imply that issues are "pre"-cooked across national boundaries. How closely administrators are involved in the actual process of scrutiny when exercising the coordination function varies between parliaments and administrators. Most of the time administrators liaise for the purpose of information gathering, but whether they also speak on behalf of their parliaments this depends on national cultures and varies from country to country (French Senate, senior EU clerk, 25/05/2012; Swedish NPR, 17/11/2010; Irish NPR, 13/01/2010). The category was nevertheless necessary as there is staff that is specifically responsible for coordination, for example the representatives of national parliaments in the European Parliament. These also meet on a regular basis to exchange information and possibly also coordinate joint actions.

\section{I.2 The Roles of Parliamentary Administrations after Lisbon}

OPAL has so far collected data on the parliaments of eight member states. Based on the interviews and written replies, the roles of administrators in the scrutiny of EU affairs can be reconstructed. ${ }^{4}$ What is striking is that while certain variations between parliaments and chambers can be observed, administrators from most chambers had at least some tasks that would be congruent with an advisory role. Overall, it seems that the Early Warning System does indeed strengthen the advisory role of administrators, in particular by giving them opportunities to set the agenda.

\footnotetext{
${ }^{4}$ For a complete list of interviews used for this paper please refer to the bibliography.
} 


\section{I.2.I The Information-Overload Advantage}

Despite initiatives on better law-making designed to reduce the number of documents the EU produces, the EU's document output is still very high. With the new rules on information provision, this led to national parliaments being swamped with information. Thus, a Belgian European Affairs clerk estimates that the House of Representatives received about 1000 documents in 2011 - a number that varies from year to year depending on the Commission work programme (Belgian House of Representatives, EAC clerk, 25/05/2012). As a result, all of the parliaments channel this information flow via their administration. However, the European Affairs staff does not just act as a "mailbox", but - in all cases - preselects documents based on their relevance for the Member State and political salience, either based on the Commission Work Program, the weekly list of proposals or both. These lists of priorities are usually subject to the approval of the European Affairs Committee, Specialized Committees or the Chair of the European Affairs Committee, but administrators agree that their lists are most of the time accepted by their political masters (House of Commons, EAC clerk, 23/05/2012; French Senate, advisor, 4/05/2012, (Dutch Parliament, NPR, 09/12/2010). In quantitative terms, the Belgian European Affairs clerk estimates that about 100-200 out of 1000 documents are short-listed by the parliamentary staff (Belgian House of Representatives, EAC clerk, 25/05/2012). The Dutch parliament selected "priority dossiers" for subsidiarity on an annual basis, basis, but also other EU issues (around 8o in total per year) (Dutch Parliament, NPR, 09/12/2010). In practice, this filtering role gives parliamentary staff a measure of influence over the European Affairs agenda of parliaments (to the extent that they can deselect documents and concentrate their attention on a number of selected dossiers). In order to ensure that important dossiers get noticed, some parliamentary staff in addition recommend that committees scrutinize these dossiers and advice on possible courses of action, such as scrutiny reserves or reasoned opinions (Dutch Lower House, EU Affairs clerk, 09/12/2011; Romanian Parliament, Former EU Staff, 17/11/2011).

A good illustration of this kind of pre-selection is the Austrian case. In Austria, a special division within the section of "EU and International Services" of the parliamentary administration was set up to deal with incoming documents by the Austrian government and EU institutions including the EU database (COSAC 2010, p. 13). Within the new division of the parliamentary administration, all incoming EU draft legislation is submitted to a "pre-subsidiarity" check from a legal perspective, complemented by information from the Permanent Representation in Brussels or other sources. Draft legislation that is submitted by the EU institutions is prepared and identified by way of code-words. The parliamentary administration then gives a recommendation by email to Members of Parliament (of around 3-4 per week) as regards to the issues that are to be submitted to a subsidiarity check. If relevant the issues are then put on the agenda of the Main Committee of parliament. Usually the recommendations by the parliamentary administration are 
taken seriously. It is then a political decision whether an opinion as regards to the violation of the subsidiarity principle is submitted to the EU institutions (Austrian Parliament, NPR, 22/11/2010).

The Belgian House of Representatives also established a new 'analysis unit' with three civil servants in preparation for Lisbon (Written reply, Belgian House of Representatives, 28/11/2012). In several other parliaments, the new information and participation rights led to an increase in the number of staff. The staff of the Belgian House of Representatives increased from 4 in 2006 to 7 in 2011 and the staff of the Senate from 1.5 to 3 (ibid.; Written reply, Belgian Senate, 22/11/2012). The joint staff of the two Austrian chambers increased from 10 in 2005 to 15 in 2011 as the result of the Austrian presidency in 2006 and the preparations for Lisbon (Written reply, Austrian parliament, 13/11/2012). In the Dutch Lower House, staff levels rose from 4 in 2006 to 9 in 2011 as a result of a major parliamentary reform following the negative referendum on the Constitution and anticipating the Lisbon changes (Dutch Lower House, EU Affairs clerk, 09/12/2011). In Sweden, the sectoral committees employed more EU staff to help them adapt to their role in the EWS (Written reply, Swedish parliament, 11/o9/2012). However, it should also be noted that this trend is not "universal", i.e. does not apply to all national parliaments. The German Bundesrat only employed one additional person and not specifically for Lisbon, as it felt sufficiently wellstaffed (Written reply, German Bundesrat, 6/12/2012). The French Senate reduced its EU staff by two (from 16 to 14 between 2006 and 2011; Written reply, French Senate, 19/11/2012) and the Portuguese parliament went from three administrators and one assistant in 2006 to two administrators and one assistant (Written reply, Portuguese parliament, 9/10/2012). In both cases, the financial crisis and its effect on public spending were cited as important pressures.

The role of the administration in pre-selection issues is specific to the Early Warning System and document-based scrutiny. In the case of mandating, which is based on the agenda of the Council of Ministers and the draft position of the government on these issues, the tasks of the administration are based around preparatory information provision and analysis rather than selection (Dutch Lower House, EU Affairs clerk, 09/12/2011; Swedish parliament, EAC clerk, March 2012). As a result, the ability of administrators to pre-select relevant issues seems to have been particularly strengthened by the introduction of the document-based EWS, nevertheless also in mandating systems the role of administrators is also strengthened insofar as there is a clear list of priorities that the parliament will focus on and so specific advice can be given.

\section{I.2.2 From Summaries to Advice}

While all parliamentary administrations are very involved in the earliest stages of the EWS through the filtering of documents, the practices of information provision seem to vary across parliaments and even chambers. The administration of the Dutch Lower House, the Swedish parliament and the French parliament generally provide committees with balanced arguments on 
an issue. The administration of the Romanian House of Representatives also provides an analysis upon request (Dutch Lower House, EU Affairs clerk, 09/12/2011; Swedish parliament, Social Insurance Committee clerks, March 2012; French Senate, senior EU clerk, 25/05/2012). The advantage of such a system is that administrators support the activities of MPs, but by providing them with a range of arguments and alternatives they remain relatively neutral and do not overly bias in their final choice (cf. Meller, 1952: 116). In the case of the Dutch Lower House, this presentation of both pro and contra argument is also part of an attempt to get politicians more actively involved in the scrutiny of EU affairs. The switch to this system only happened as part of the big overhaul of the EU scrutiny system of the Lower House of 2006 in reaction to the Dutch "no" vote on the Constitutional Treaty and in preparation for a Treaty that would introduce the new measures on the participation of national parliaments. Previously, the administrators often drafted the actual document before the debate, which could result in the committee simply approving a pre-prepared draft. As the committees are now confronted with potentially contradictory arguments, they have at the very least to choose from amongst the list of arguments (Dutch Lower House, EU Affairs clerk, 09/12/2011).

Those administrations that only provide summaries of documents or a list of different arguments usually also only draft parliamentary documents after the debates in the committees. The EAC staff of the German Bundesrat drafts reasoned opinions based on the debates in the Bundesrat (German Bundesrat, EAC clerk, 4/05/2012).

By contrast, some parliamentary administrations already provide drafts prior to debates in the committee, for example the European Affairs clerks of the Belgian House of Representatives and the Romanian Senate (Belgian House of Representatives, EAC clerk, 25/05/2012; Romanian Senate, EAC clerk, 5/04/2012), as well as the French parliamentary administration for reasoned opinions (French Senate, senior EU clerk, 25/05/2012).

In general, committee staff provides committees or individual MPs of all parties with information upon request, but leave the task of politically interpreting information to party or MP staff.

The duties of parliamentary staff with regard to mandating are similar to those under parliamentary scrutiny in this regard. Administrators gather information on the Council meeting and government position and advise the relevant committee (Swedish Parliament, EAC clerk, March 2012). In the case of the Dutch parliament, the administration sometimes also suggests possible questions that might be relevant in that context (Dutch Lower House, EU Affairs clerk, 09/12/2011).

Overall, the practices of parliamentary administrations thus vary more in the field of drafting and provision of advice than with regard to the pre-selection of documents. Some of these differences 
are motivated by different national cultures, i.e. what MPs and administrators perceive to be the "right" way of doing things. The decision of the EU staff of the Dutch Lower House to provide balanced arguments is a case in point. However, there are other factors that induce variation. The staff of the Belgian Senate, for example, merely forwards the relevant documents to the relevant committees, but does not provide drafts of any kind. The main reason for this choice is that it has only three members of EU staff, who have to manage all EU-related activities. As the Belgian parties were (and are) very pro-European, it was not deemed necessary to increase the number of staff as interest in the scrutiny of EU affairs was low. In addition, the role of the Senate itself is under debate. As a result, the kind of support that can be provided is limited. The advantage is, of course, that politicians are not biased by administrators and truly take their own decision. The downside is that it is extremely difficult for a committee to write a draft from scratch (Belgian Senate, EAC clerk, 16/o4/2012).

\section{I.2.3 A Hub for Coordination}

The key players with regard to inter-parliamentary coordination and exchange between EU institutions and national parliaments are the permanent representatives of the parliaments in the EP (hereafter: NPRs). Each parliament with the exception of Slovakia has a representative at the $\mathrm{EP}$, and some bicameral parliaments have one for each chamber.

The Danish parliament is a forerunner in this respect as it has sent a permanent representative to Brussels to cover EU affairs since already 1990. The reason behind this was that the Danish parliament was the first to deal with EU issues quite intensively by way of their system of mandating the respective minister in the Council, so this came rather naturally (Danish NPR, 09/11/2010). The Finnish parliament also decided to send a representative in 1996 due to the fact that information of the government often arrived too late und was not always seen of a reliable nature. The Swedish parliament then built on these experiences and sent a permanent representative to Brussels since 2005; prior to that a delegate was only sent to cover strategic issues such as for the Swedish Presidency and the Convention (Hegeland, in: Raunio and Brennan 2007, Swedish NPR, 17/11/2010). A majority of the representatives have worked in their respective parliaments before, so they have a first comprehensive insight into their respective legislative system.

Building on the provisions of the Lisbon Treaty as a legal basis, national parliamentary representatives to the EP have derived a common task for themselves, which is the exchange of information on the stance of their respective parliament towards a possible breach of the principle of subsidiarity from the perspective of one or more Member States. The informal network of NPRs is beginning to function by way of the regular "Monday morning meetings". It is in this setting that national parliamentary representatives exchange information and "alert" other 
parliaments to proposals that could be problematic both from the perspective of the subsidiarity principle or from a more political stance. Moreover, the fact that all representatives work in the same building builds a basis for informal information exchange, where this "bridge-building function" across national parliaments is flagged up as one of the main functions of NPRs (Dutch NPR, 9/12/2010; Slovenian NPR, 16/11/2010).

Apart from contributing to a fruitful information-exchange between national parliamentary representatives, the respective parliamentary officials have the main tasks of creating a network of contacts with the European institutions and to participate in their respective meetings as well as in meetings of their respective national parliaments. The direct contact with the EU executive is inter alia facilitated by the fact that representatives of the services of the Commission regularly attend the meetings of NPRs (Commission 2010, p. 7; COSAC clerk, 09/11/2010). Moreover representatives are to supply data for the scrutiny activities of their respective parliaments and to ensure cooperation with their respective Permanent Representation to the European Union. This is facilitated in Member States such as France where the NPR does not only have an office in Paris (within the French national assembly) but also one in the EP and one in the French Permanent Representation. The French NPR thus has access to all information as regards to Council Working Groups (French NPR, 14/09/2010).

On top of that NPRs are to contribute to the exchange of best practices when it comes to exerting parliamentary control. Overall the tasks of the NPRs can be summarized as follows:

a. Antennae for the respective national parliaments by providing a link between the EU arena and the domestic level and thus alerting Members of Parliament (MPs) to EU affairs and issues that are negotiated at the European level;

b. Representational function: This includes working visits of MPs to Brussels and bringing MPs in contact with representatives of the EU institutions such as with MEPs or Commissioners.

c. Bridge-building function across national parliaments : Within the Monday Morning Meetings for example, NPRs exchange first-hand information across national parliaments by informing each other about the respective stance of a national parliament towards a Commission proposal and this can contribute to the coordination of positions.

The EU experts in the national parliaments, by contrast, do not have many direct contacts to other national parliaments and only some contacts to EU institutions. They rely mostly on the NPRs for these contacts (e.g. French Senate, EAC clerk, 12/05/2012; Dutch Senate, 2 EAC clerks, 11/o1/2011; Dutch Lower House, EU Affairs clerk, 09/12/2011; House of Commons, EAC clerk, 23/05/2012). This means that de facto most interparliamentary cooperation and requests for information have to run via Brussels and the NPR network. As the Early Warning System encourages inter-parliamentary cooperation, parliamentary staff have started to see the advantage 
of a better network of administrators. As a result, due to a Dutch initiative, a meeting of EAC clerks took place after the COSAC meeting of April 2012 (COSAC, 24/05/2012). It was not the first meeting of parliamentary staff, but the first in many years and was motivated by the increased need for coordination (Folketing, EU Advisor, 19/11/2012).

However, the main contacts of EU experts outside their chamber are still often with officials in the ministries for the purpose of information gathering. In the Netherlands, cooperation between the two chambers is also ensured mainly via administrative cooperation. Thus, the EU staff of the Senate takes part regularly in the Tuesday morning meetings of the EU staff of the Lower House. Even when the two chambers issue joint reasoned opinions, the coordination takes place mostly via the administration. However, this close cooperation is specific to the Netherlands. Neither the French nor the Belgian chambers work so closely together and thus neither do their administrations (Dutch Senate, 2 EAC clerks, 11/o1/2011; Dutch Lower House, EU Affairs clerk, 09/12/2011; Belgian Senate, EAC clerk, 16/o4/2012; French Senate, EAC clerk (1), 25/o5/2012).

\section{I.2.4 Conclusion}

Overall, the preparation for and implementation of the Treaty of Lisbon has allowed administrators to play a more active role in EU affairs. The great number of EU documents received by national parliaments and the short period for parliamentary reactions has led to a preselection of documents by administrators in all eight countries studied. This allows administrators to become active advisors and even steer parliamentary business, especially if "driven" administrators use it to flag up a few core issues and facilitate their treatment through with procedural and substantive advice. Administrative practice on drafting and advising still varies from chamber to chamber, partly due to different perceptions of what is "good" practice and partly due to the limited capacity of smaller administrations. In addition, administrators have taken on an important role in information gathering, especially through the NPRs in Brussels. Thus, overall, the roles of administrators do not conform to one specific type of role, assistant, analyst, advisor or coordinator, but combine different elements from the different sets of categories. However, due to their role in the pre-selection of documents, all EU staff now seems to perform elements of an advisory role.

\section{Political Oversight in National Parliaments}

The first empirical insights into the roles of parliamentary administrations in the scrutiny of EU affairs thus indicate that administrators in most parliaments actively participate in the scrutiny at several points in the process. At the same time, an active role on the part of the administrators should not be confused with bureaucratic domination or the rule of unelected officials, i.e a run- 
away bureaucracy (Lowi 1979). As mentioned previously, legislatures have developed various strategies of dealing with the delegation of tasks to bureaucrats. Just like the literature on parliamentary administrations, the literature on parliamentary oversight over bureaucrats is not very extensive. Scholars have done research on parliamentary oversight in the case of the US Congress for several decades, though, and produced some valuable concepts and insights - albeit in the context of executive bureaucrats in agencies, i.e. bureaucrats that are external to the functioning of the parliament itself.

Within the literature on the US Congress, three approaches stand out. Firstly, Arnold introduces a distinction between forms of statutory techniques, non-statutory techniques and administrative rules and procedures. Statutory techniques are the use of authorization or re-authorization bills of programs or budgetary bills to provide guidelines or prohibitions to agencies. Non-statutory techniques comprise the use of hearings and reports to control bureaucratic activity. Finally, administrative rules and procedures allow legislatures to make agencies transparent and create channels of appeal for interested parties (Arnold, 1987: 208-1). McCubbins and Schwartz distinguish between "police-patrol" and "fire-alarm" oversight. Police-patrol oversight requires the legislature to regularly check samples of an agency's work, whereas fire-alarm oversight relies on citizens and interested parties to examine administrative decisions. A system of rules and procedures allows for access to information and establishes the rights of appeal (McCubbins and Schwartz, 1984: 166). Finally, in the context of governments and executives, Huber distinguishes between ex ante and ex post institutions. Ex ante institutions kick in before civil servants take action, whereas ex post institutions serve as a remedy. One ex ante remedy would be to allow politicians to select suitable (and potentially politicized) civil servants that sympathize with the views of the politician/government. Other ex-ante measures are again administrative rules and tight legislation. Ex post instruments include hearings and Courts. Tight budgets can be used both ways - to sanction certain behaviors or to prevent certain actions (Huber, 2000: 399-401).

Overall, the different classifications overlap and can be combined in the following way: 
Table 2: Parliamentary Oversight over Executive Bureaucracies (based on Arnold 1987, McCubbins and Schwartz 1984, Huber 2000)

\begin{tabular}{|c|c|c|}
\hline & Ex-ante (prevention) & Ex-post (correction) \\
\hline Statutory & $\begin{array}{ll}\text { - } & \text { tight laws } \\
\text { - } & \text { reauthorization bills } \\
\text { - } & \text { budget } \\
\end{array}$ & - budget \\
\hline Non-statutory & $\begin{array}{l}\text { - } \quad \text { politicized } \\
\text { appointments }\end{array}$ & $\begin{array}{ll}\text { - } & \text { hearings } \\
\text { - } & \text { reports } \\
\text { - } & \text { appeal to courts } \\
\end{array}$ \\
\hline Admin. rules and procedures & $\begin{array}{l}\text { - on consultations and } \\
\text { stakeholder hearings }\end{array}$ & $\begin{array}{l}\text { - } \quad \text { on transparency } \\
\text { - } \quad \text { on appeals }\end{array}$ \\
\hline
\end{tabular}

However, as in the case of the roles of executive bureaucrats, the literature on the control of agencies and bureaucrats in executives cannot be transferred one-to-one to political oversight over administrators within parliaments. In fact, virtually all instruments are either not applicable to parliamentary staff due to its specific set of tasks or too formal or would backfire. The main difference is that political oversight in the case of agencies is about controlling administrators when they implement and manage policies after parliament has adopted a policy. In the case of parliamentary staff, in particular under the EWS, it is about controlling administrative activity that precedes parliamentary decisions. Parliamentary staff is usually involved in the preparation of a parliamentary decision, not in the long-term management of policies. Thus, the use of laws and reauthorization of bills and administrative rules on appeals, transparency and stakeholder hearings only make sense in the context of policy-related activity where decision-making is delegated to bureaucrats. Hearings with one's own staff would be an overly formal approach and both budgetary instruments and the appointment of politicized staff would backfire in the context of parliamentary staff. In the case of the former, budgetary cuts to punish or constrain "rebellious" staff would effectively deprive politicians of their support. Politicized appointments may work in the case of politically homogeneous governments, but parliamentary staff is generally expected to respond to all parties, so that politicized staff would only generate and reinforce conflicts.

Overall, the instruments available for political oversight over parliamentary administrations are thus somewhat different. In order to avoid conflict, national parliaments generally try to ensure that parliamentary staff is politically neutral and at the service of all parties. The ex-ante measures can take the form of rules on the political neutrality of civil servants and politically neutral appointments. In France and Belgium, for example, parliamentary staff is recruited through a 
concours and French law imposes strict neutrality requirements on civil servants (Baron, 2013; Belgian Senate, EAC clerk, 16/o4/2012; Belgian House of Representatives, EAC clerk, 25/o5/2012, French NPR, $14^{\text {th }}$ September 2010).

Ex-post correction of administrative behavior is much simpler in the case of legislatures. As all final decisions are taken by MPs either in committees or in the plenary, MPs can simply ignore administrative advice and drafts, sidelines administrators that are seen as biased, circumvent parliamentary staff with the help of group staff or personal assistants or, in extreme cases, restructure the administration. After all, legislative staff can only be as influential as legislators allow them to be (DeGregorio, 1994: 2; Winzen 2011). On the other hand, one could argue that political oversight is much harder for (small) minority parties than for majority parties. As political oversight de facto relies on MPs having the last word, it can be very difficult for opposition parties to hold a biased administration in check if it has the support of the majority (cf. Manley, 1968).

Political oversight in EU affairs indeed largely relies on the simple fact that decisions are ultimately taken by politicians, not by administrators. The final decision on whether a document is in breach of subsidiarity or not lies with the relevant committee or the plenary and what a minister should or should not say in the Council is also agreed during committee debates. In general, interviewees mentioned few instances of disagreement between administrators and MPs beyond the fact that, occasionally, an issue is added to or removed from the list of issues to watch. Interestingly, the most frequently voiced concern of administrators seems to be the fear that what they do might not be taken up because of a lack of interest in the scrutiny of EU affairs on the part of politicians. The view of Belgian committee clerks is, for example, that the Treaty of Lisbon had not much impact on their parliament, because politicians were too pro-European to have an interest in EU scrutiny (Belgian Senate, EAC clerk, 16/04/2012; Belgian House of Representatives, EAC clerk, 25/05/2012). Similarly, French clerks have expressed the views that some committee chairs did not view the EWS as something desirable (French Senate, advisor, 4/05/2012). Also Romanian clerks feel that MPs in their committees are not always as interested in certain EU issues as they themselves (Romanian Senate, 2 clerks European Division, 12/04/2012). Thus, the predominant constraint on administrative activity might in practice be to get MPs to take up the issues raised by administrators.

\section{Conclusion: Administrations on the Rise?}

The Treaty of Lisbon has created new opportunities for national parliaments, but also for their administrations. In particular the work-intensive system of document-based scrutiny under the new Early Warning System de facto requires parliaments to delegate the task of filtering and preselecting relevant documents to their EU staff. In the process, administrators gain a certain 
agenda-setting power. In those cases where administrators provide additional procedural or substantial advice and recommend that the parliament take action on a proposal, the agendasetting role can gain further importance.

With regard to advising and drafting, there are marked differences in the practices of the various parliamentary administrations. While some administrators draft parliamentary documents prior to debates, others only provide an overview over a range of arguments or draft documents after debates. These differences are partially due to different perceptions of good parliamentary practice and partially due to the different capacities of parliamentary administrations.

In addition, EU staff plays an important role in the coordination between national parliaments, as in this case of Permanent Representatives of the national parliaments in the European Parliament are best placed to engage in information exchange on a regular basis and alert other parliaments to important proposals.

Nevertheless, while the Treaty of Lisbon with its document-heavy procedures has thus certainly led to a certain degree of bureaucratization of parliamentary business, this should not disguise the fact that the final decisions are taken by MPs in the (European Affairs or sectoral) committees and plenary. The greatest impact of administrators on the scrutiny of EU affairs stems probably from their attempts to promote the discussion and scrutiny of important European issues within their parliaments.

Overall, the first empirical insights into the role of parliamentary administrations in the scrutiny of EU affairs highlight nevertheless the fact that parliamentary administrators are often more than mere paper-pushers and play an important role, especially as regards to information provision, filtering and analysis. One of the tasks for future research will thus be to explore further the differences between national systems of parliamentary administrative support as well as the factors explaining the variation in administrative organization and tasks. 


\section{Bibliography}

Arnold, R.D. (1987). Political Control of Administrative Officials. Journal of Law, Economics E Organization, 3(2), 279-286.

Baron, F. (2013, forthcoming). Civil servants: how to support the political level: The French Case. In: C. Neuhold, S. Vanhoonacker and L. Verhey (eds.) Civil Servants and Politics. Basingstoke: Palgrave.

Blischke, W. (1981). Parliamentary staffs in the German Bundestag. Legislative Studies Quarterly, $6(4), 533-558$.

Campbell, S. and Laporte, J. (1981). The staff of the parliamentary assemblies in France. Legislative Studies Quarterly,6(4), 521-531.

Christiansen, T., Högenauer, A.L. \& Neuhold C., The Europeanisation of National Parliaments Post-Lisbon: Bureaucratisation and Transnationalisation rather than more democracy in the European Union?, ECPR General Conference, Reykjavik, 27 August 2011.

Cooper, I. (2012) A 'Virtual Third Chamber' for the European Union? National parliaments after the Treaty of Lisbon. West European Politics, 35(3), 441-465.

COSAC (2010): Thirteenth Bi-annual Report: Developments in European Union Procedures and Practices Relevant to Parliamentary Scrutiny, Prepared by the COSAC Secretariat and presented to: XLIII Conference of Community and European Affairs Committees of Parliaments of the European Union, 31. May - 1. June 2010.

DeGregorio, C. (1994), Professional Committee Staff as Policy Making Partners in the US Congress. Congress \& The Presidency, 21(1), 49.

Dobbels, M. \& Neuhold, C., The Roles Bureaucrats Play: The Input of European Parliament (EP) Administrators into Co-Decision. UACES Conference, Cambridge 7 September 2011.

Egeberg, M., Gornitzka, A., Trondal, J. and Johannessen, M. (2012) Parliament Staff: Unpacking the Behaviour of Officials in the European Parliament, Journal of European Public Policy, DOI: 10.1080/13501763.2012.718885, 1-20.

EU Observer, 5 October 2006, "Commission bureaucrats are getting too powerful", http://euobserver.com/?aid=22572. 
European Council (2001), Laeken Declaration on the Future of the European Union, http://european-convention.eu.int/pdf/lknen.pdf.

European Communities (2004) Staff Regulations of Officials of the European Communities, http://ec.europa.eu/dgs/personnel administration/statut/tocenıo.pdf

Hegeland, H. (2007). The European Union in national parliaments: domestic or foreign policy? A study of Nordic parliamentary systems. In: O’Brennan and Raunio (eds.), National Parliaments within the Enlarged European Union: From 'victims' of integration to competitive actors?, Abingdon: Routledge, 95-115.

Huber, J. (2000). Delegation to Civil Servants in Parliamentary Democracies. European Journal of Political Research, 37, 397-413.

Kiiver, P. (2012). The Early Warning System for the Principle of Subsidiarity. Constitutional theory and empirical reality. London and New York: Routledge.

Lowi, T. (1979) The end of liberalism (New York: W. W. Norton \& Company).

Manley, J.F. (1968). Congressional Staff and Public Policy-Making: The Joint Committee on International Revenue Taxation. The Journal of Politics, 30(4), 1046-1067.

McCubbins, M.D. \& Schwartz, T. (1984). Congressional Oversight Overlooked: Police Patrols versus Fire Alarms. American Journal of Political Science, 28(1), 165-179.

Meller, N. (1952). The Policy Position of Legislative Service Agencies. The Western Political Quarterly, 5(1), 109-123.

Neunreither, K. (2006). Elected legislators and their unelected assistants in the European Parliament. Journal of Legislative Studies, 8(4), 40-6o.

Page, E., \& Jenkins, B. (2005). Policy Bureaucracy: Government with a Cast of Thousands. Oxford: Oxford University Press.

Patterson, S. (1970). The Political Staffs of Congressional Committees. Administrative Science Quarterly, 25(1), 22-38.

Provan, J. (2001), Working Document No. 6 on Internal Reform: " Legislative Assistance to Members - A Rethink. 
Perez, S. (2007). Parlament et administration de l'Union européenne. In Annuaire européen d'administration publique: Tome 29, Parlement et administration en Europe. PU AixMarseille.

Raunio, T. (2007) National legislatures and the Constitutional Treaty. In: J. O'Brennan and T. Raunio (eds.) National Parliaments within the Enlarged European Union: From 'victims' of integration to competitive actors?. Abingdon: Routledge, pp. 79-92.

Raunio, T. (2010) Destined for Irrelevance? Subsidiarity Control by National Parliaments, Europe Working Paper, 2010(36), Real Instituto Elcano

Ryle, M. T. (1981). The legislative staff of the British House of Commons. Legislative Studies Quarterly, 6(4):497-519.

Winzen, T. (2011). Technical or Political? An Exploration of the Work of Officials in the Committees of the European Parliament. Journal of Legislative Studies, 17(1), 27-44. 


\section{Interviews}

1. Austrian NPR, 22/11/2010.

2. Belgian House of Representatives, EAC clerk, 25/05/2012.

3. Belgian Senate, EAC clerk, 16/o4/2012.

4. COSAC clerk, 09/11/2010

5. Danish NPR, 09/11/2010

6. Dutch Lower House, EU Affairs Clerk, 9/12/2011.

7. Dutch Lower House, VVD MP, EAC, 23/03/2012.

8. Dutch NPR, 09/12/2010

9. Dutch Senate, 2 EAC clerks, 11/o1/2011.

10. Finish NPR, 16/11/2010

11. Folketing, EU Advisor, 19/11/2012

12. French NPR, 14/o9/2010

13. French Senate, advisor, 4/05/2012.

14. French Senate, EAC clerk (1), 25/05/2012.

15. French Senate, EAC clerk, 12/05/2012.

16. French Senate, senior EU clerk, 25/05/2012.

17. German Bundesrat, EAC clerk, 4/05/2012.

18. House of Commons, EAC clerk, 23/05/2012.

19. Irish NPR, 13/01/2010).

20. Romanian Parliament, Former EU Staff, 17/11/2011.

21. Romanian Senate, 2 clerks European Division, 12/04/2012.

22. Romanian Senate, EAC clerk, 5/04/2012.

23. Slovenian NPR, 16/11/2010

24. Swedish NPR, 17/11/2010

25. Swedish Parliament, EAC clerk, March 2012.

26. Swedish parliament, Social Insurance Committee clerks, March 2012

27. Written reply, Austrian parliament, 13/11/2012

28. Written reply, Belgian House of Representatives, 28/11/2012

29. Written reply, Belgian Senate, 22/11/2012

30. Written reply, French Senate, 19/11/2012

31. Written reply, German Bundesrat, 6/12/2012

32. Written reply, Portuguese parliament, 9/10/2012

33. Written reply, Swedish parliament, 11/o9/2012 


\section{Authors}

Anna-Lena Högenauer is an NWO-funded Postdoctoral Researcher at the Faculty of Arts and Social Sciences, Maastricht University. She is a member of the OPAL project (Observatory of Parliaments after the Lisbon Treaty), which is funded by the NWO, ESRC, ANR and DFG. She is working on the representation of regions and national parliaments in the European Union.

Christine Neuhold is Associate Professor of European Governance within the Department of Political Science, Faculty of Arts and Social Sciences, Maastricht University. She is Director of the Research Master European Studies and Co-coordinator (with Sophie Vanhoonacker) of an Initial Training Network on Dynamics of Inter-institutional Cooperation in the EU (INCOOP), financed by the EU. She has published widely on different aspects of EU policy-making and on EU institutions. 